\title{
Proteomic responses induced by metal pollutions in oysters Crassostrea sikamea*
}

\author{
LU Zhen ${ }^{1,3}$, SHAN Xiujuan ${ }^{2,4}$, JI Chenglong ${ }^{1,2, * *}$, ZHAO Jianmin ${ }^{1}$, WU Huifeng ${ }^{1,2}$ \\ ${ }^{I}$ Key Laboratory of Coastal Zone Environmental Processes, Yantai Institute of Coastal Zone Research (YIC), Chinese Academy \\ of Sciences (CAS); Shandong Provincial Key Laboratory of Coastal Zone Environmental Processes, YICCAS, Yantai 264003, \\ China \\ ${ }^{2}$ Function Laboratory for Marine Fisheries Science and Food Production Processes, Qingdao National Laboratory for Marine \\ Science and Technology, Qingdao 266237, China \\ ${ }^{3}$ University of Chinese Academy of Sciences, Beijing 100049, China \\ ${ }^{4}$ Key Laboratory of Sustainable Development of Marine Fisheries, Ministry of Agriculture; Shandong Provincial Key Laboratory \\ of Fishery Resources and Ecological Environment, Yellow Sea Fisheries Research Institute, Chinese Academy of Fishery \\ Sciences, Qingdao 266071, China
}

Received Mar. 20, 2018; accepted in principle May 2, 2018; accepted for publication Jul. 2, 2018

(C) Chinese Society for Oceanology and Limnology, Science Press and Springer-Verlag GmbH Germany, part of Springer Nature 2019

Abstract There exist severe metal pollutions along the Jiulongjiang estuary in South China. In order to unravel the biological effects caused by metal pollutions, proteomic responses were investigated by two-dimensional electrophoresis-based proteomics in oysters Crassostrea sikamea from metal pollution sites, Jinshan (JS) and Baijiao (BJ), and a relatively clean site, Jiuzhen (JZ), along the Jiulongjiang estuary. Results indicated that metal pollutions mainly induced cellular injuries, oxidative and immune stresses, and disturbed ion homeostasis in oysters $C$. sikamea from both JS and BJ sites via differential pathways. Furthermore, metal pollution enhanced transcriptional initiation in oysters from JS site. In addition, the $\mathrm{Cu}$ and Fe pollution might be indicated by the $78 \mathrm{kDa}$ glucose regulated protein and ferritin GF1 in oysters C. sikamea, respectively. The study confirms that proteomics is a promising approach to characterize the underlying mechanisms of responses to metal pollution in oysters.

Keyword: metal pollution; Crassostrea sikamea; biological effect; proteomics

\section{INTRODUCTION}

With the rapid development of industry, marine and coastal metal pollution has become a serious environmental problem along the Jiulongjiang estuary in South China. Previous reports indicated that severe metal contamination has been found in sediments and organisms sampled in this area (Liu and Wang, 2012; Weng and Wang, 2014; Tan et al., 2015; Lin et al., 2016). Significantly, two species of oysters, Crassostrea hongkongensis and Crassostrea sikamea, have been found to accumulate high accumulation of metals, which have posed a great risk on human health. Luo et al. (2014) found the blue colored oysters showing the severe $\mathrm{Cu}$ pollution in the Jiulongjiang estuary. As it is known, the excessive uptake of metals (such as $\mathrm{Cd}$ and $\mathrm{Cu}$ ) can induce toxic effects in aquatic organisms (Cecconi et al., 2002; Bertin and Averbeck, 2006).

Marine filter-feeders, such as mussels, clams, scallops and oysters, are not only consumed as seafood but play important roles in maintaining marine ecosystem health (Weng and Wang, 2014). Our previous study indicated that the oyster C. sikamea distributed along the coast in South China could accumulate very high levels of $\mathrm{Cu}$ and $\mathrm{Zn}$, up to 7000 and $9000 \mu \mathrm{g} / \mathrm{g}$ dry weight, respectively (Ji et

\footnotetext{
* Supported by the National Natural Science Foundation of China (Nos. 41676114, 21237004, 41506138), the Qingdao National Laboratory for Marine Science and Technology (No. QNLM201701), and the "Youth Innovation Promotion Association CAS" (No. 2015169) ** Corresponding author: clji@yic.ac.cn
} 


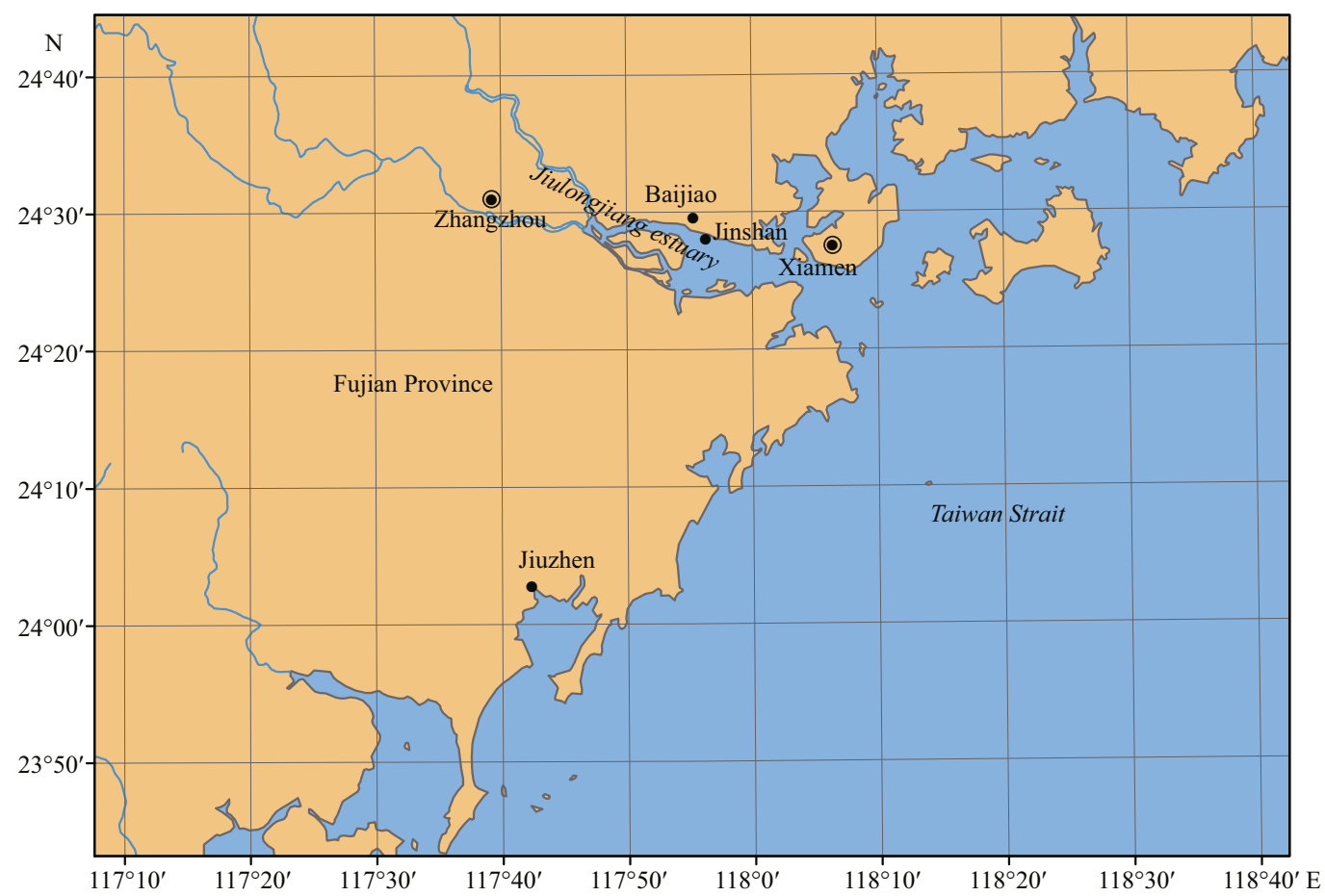

Fig.1 The map showing the locations of sampling sites along the Jiulongjiang estuary, Fujian Province, China

al., 2016). Due to the high capability to accumulate metals, oysters are used as preferable environmental bioindicators for metals (Goldberg et al., 1983). In this study, therefore, the oyster C. sikamea was used to investigate the biological effects of metal pollution along the Jiulongjiang estuary in South China.

Traditional ecotoxicology studies, consisting of bioaccumulations and responses of targeted genes and biochemical indices, has been increasingly applied to metal pollution monitoring in environment watch programs (Rank et al., 2007; Kim et al., 2011). However, these studies do not enable the global view on the biological effects of metal pollutions in bioindicators. With the emergence of system biology, a global analysis on the biological effects induced by environmental pollutants can be conducted at molecular levels (gene, protein and metabolite) (Knigge et al., 2004; Cappello et al., 2013). As a system biology approach, proteomics can compare the whole proteome profiles in environmental bioindicators from normal and metal polluted sites, which may explain the biological responses to metal pollution. Considering its potential capability of unraveling the mechanisms of responses to pollutants, comparative proteomics has been becoming a useful diagnostic tool to assess the effects of environmental pollution (Monsinjon and Knigge, 2007; Campos et al., 2012; Tomanek, 2014).

In this study, the two-dimensional electrophoresis
(2-DE)-based proteomics was applied to study the proteomic responses and characterize the biological effects in oyster (Crassostrea sikamea) exposed to metal pollutions. The samples of oyster $C$. sikamea were collected from three sites (Baijiao (BJ); Jinshan (JS); Jiuzhen (JZ)) along the Jiulongjiang estuary, Fujian Province, China. Our previous study showed that JZ site was a relatively clean site and therefore regarded as a reference (Xu et al., 2016). Comparatively, both JS and BJ sites were severely polluted by multiple metals (especially copper and zinc) (Weng and Wang, 2014; Tan et al., 2015; Ji et al., 2016).

\section{MATERIAL AND METHOD}

\subsection{Samples collection}

During the low tides, the oysters $C$. sikamea with an average size of $2 \mathrm{~cm}$ were collected from JS $\left(24^{\circ} 29^{\prime} 36^{\prime \prime} \mathrm{N}, \quad 117^{\circ} 55^{\prime} 17^{\prime \prime} \mathrm{E}\right), \quad$ BJ $\quad\left(24^{\circ} 28^{\prime} 2^{\prime \prime} \mathrm{N}\right.$, $\left.117^{\circ} 56^{\prime} 19^{\prime \prime} \mathrm{E}\right)$ and $\mathrm{JZ}\left(24^{\circ} 2^{\prime} 38^{\prime \prime} \mathrm{N}, 117^{\circ} 42^{\prime} 26^{\prime \prime} \mathrm{E}\right)$ sites, respectively (Fig.1). The whole practical procedures for oyster sampling were strictly conducted according to the guidelines suggested by Hines et al. (2007) and Vidal-Liñán and Bellas (2013). Oysters with similar sizes were randomly collected from the three sites, and the whole soft tissues were immediately dissected and flash frozen in liquid $\mathrm{N}_{2}$, followed by storage in $-80^{\circ} \mathrm{C}$ in laboratory. 


\subsection{Protein extraction}

For each sampling site, 3 biological replicates each containing 3 individual oysters were used for further proteomic analysis. Every three individuals were pooled into one sample as one replicate for protein extraction. Total protein extraction was performed according to a protocol modified by Wu et al. (2013a). Briefly, $1 \mathrm{~mL}$ TRIzol reagent was added to the oyster samples, and then the mixture was homogenized quickly on ice. The suspension was centrifuged at $12000 \times g$ for $5 \mathrm{~min}$ at $4{ }^{\circ} \mathrm{C}$, and the supernatant was added with $200 \mu \mathrm{L}$ of chloroform, followed by shaking vigorously and precipitating for $3 \mathrm{~min}$. After centrifugation, the lower organic layer was added with an equal volume of absolute ethyl alcohol, and the mixture was then centrifuged at $2000 \times g$ for $5 \mathrm{~min}$ at $4^{\circ} \mathrm{C}$. The precipitation was conducted on the phenol/ethanol supernatant by addition of $750 \mu \mathrm{L}$ of isopropanol for $30 \mathrm{~min}$ at room temperature, followed by centrifugation at $14000 \times g$ for $10 \mathrm{~min}$ at $4{ }^{\circ} \mathrm{C}$. The pellets were washed twice with ethanol (v/v 95\%) and then centrifuged for $10 \mathrm{~min}$. The lysis buffer $(7 \mathrm{~mol} / \mathrm{L}$ urea, $2 \mathrm{~mol} / \mathrm{L}$ thiourea, 4\% (w/v) CHAPS, $65 \mathrm{mmol} / \mathrm{L}$ DTT and $0.2 \%(\mathrm{v} / \mathrm{v})$ Bio-lyte buffer) was added to the pellets, and the homogenate was centrifuged at $15000 \times g$ for $10 \mathrm{~min}$ and the supernatant was applied to protein concentration determination and electrophoresis.

\subsection{Two-dimensional gel electrophoresis}

The total protein concentration was firstly measured by Protein Assay Kit of Tiangen, based on BCA method by TianGen. For the isoelectric focusing (IEF), $130 \mu \mathrm{g}$ of protein was loaded onto IPG strips with a linear $\mathrm{pH}$ gradient from 4 to 7 (Immobiline Drystrip TM $24 \mathrm{~cm}$, GE Healthcare, USA). The IEF solution consists of $7 \mathrm{~mol} / \mathrm{L}$ urea, $2 \mathrm{~mol} / \mathrm{L}$ thiourea, 4\% (w/v) CHAPS, $65 \mathrm{mmol} / \mathrm{L}$ DTT, 0.001\% (v/v) bromophenol blue and $0.2 \%(\mathrm{v} / \mathrm{v})$ Bio-lyte buffer. Ettan IPGphor3 system was used to perform IEF at $20^{\circ} \mathrm{C}$ for a total of $85858 \mathrm{Vh}$ (active rehydration was carried out at $30 \mathrm{~V}$ for $12 \mathrm{~h}$, followed by $100 \mathrm{~V}$ for $5 \mathrm{~h}, 500 \mathrm{~V}$ for $1 \mathrm{~h}, 1000 \mathrm{~V}$ for $1 \mathrm{~h}$, and a linear increase of voltage to $8000 \mathrm{~V}$ for $11 \mathrm{~h}$ and stand by $500 \mathrm{~V}$ for the second dimension). After IEF, two times of equilibration were sequentially conducted on the strips in buffer $1(0.05 \mathrm{~mol} / \mathrm{L}$ Tris- $\mathrm{HCl}, \mathrm{pH} 8.8$; $6 \mathrm{~mol} / \mathrm{L}$ urea; 30\% (v/v) glycerol; 2\% (w/v) SDS; containing $1 \%(\mathrm{w} / \mathrm{v}) \mathrm{DTT})$ for $15 \mathrm{~min}$ and buffer 2 (0.05 mol/L Tris-HCl, pH 8.8; 6 mol/L urea; $30 \%$ (v/v) glycerol; $2 \% \quad(\mathrm{w} / \mathrm{v}) \quad \mathrm{SDS} ; \quad 2.5 \% \quad(\mathrm{w} / \mathrm{v})$ iodoacetamide) for $15 \mathrm{~min}$. Then the second dimension was conducted on 12.5\% SDS-PAGE gels using the Ettan DALTsix system. The images of gels stained with silver were captured by ImageScanner III and spots were quantitatively analyzed using ImageMaster 2D Platinum 7.0. In this study, only protein spots with significant changes of at least 1.5fold, and deemed significant by Student's $t$-test at a level of $95 \%$ were accepted as differentially expressed proteins.

\subsection{Protein identification}

In-gel digestion was performed according to Katayama et al. (2001). In brief, the spots detected on the gel were excised and subjected to digestion into peptides with trypsin. The samples were then dried and re-suspended with $5 \mu \mathrm{L}$ of $0.1 \%(\mathrm{v} / \mathrm{v})$ TFA, followed by mixing in 1:1 ratio with a saturated solution of $\alpha$-cyano-4-hydroxy-trans-cinnamic acid in $50 \%(\mathrm{v} / \mathrm{v})$ acetonitrile (Shevchenko et al., 1996). Subsequently, the mixture was analyzed by an ABI 4800 MALDI-TOF/TOF Plus mass spectrometer (Applied Biosystems, Foster City, USA), and the data were acquired in a positive MS reflector using a CalMix5 standard to calibrate the instrument (ABI4800 Calibration Mixture). Based on the integrated and processed MS and MS/MS data, proteins were successfully identified based on $95 \%$ or higher confidence interval of their scores in the MASCOT V2.4 search engine (Matrix Science Ltd., London, UK) with acetyl, carbamidomethyl, deamidated, dioxidation, oxidation modifications, fragment mass tolerance $\pm 0.5 \mathrm{Da}$, and 1 missed cleavages site. The NCBInr Metazoa (Animals) (2 861494 sequences) database was used in the search and individual ions scores $>40$ indicate identity or extensive homology $(P<0.05)$.

\section{RESULT AND DISCUSSION}

In this study, 2-DE-based proteomics was conducted on oysters $C$. sikamea to investigate the proteomic responses induced by metal pollutions (Fig.2). In total, over 1000 protein spots were resolved in the 2-DE gels from the oyster samples, among which 24 and 15 spots were differentially expressed $(>1.5$ folds, $P<0.05)$ in the oyster samples from JS and BJ sites, respectively. Figure 2 indicates the differential protein spots in oysters $C$. sikamea sampled from the contaminated sites (JS and BJ) 


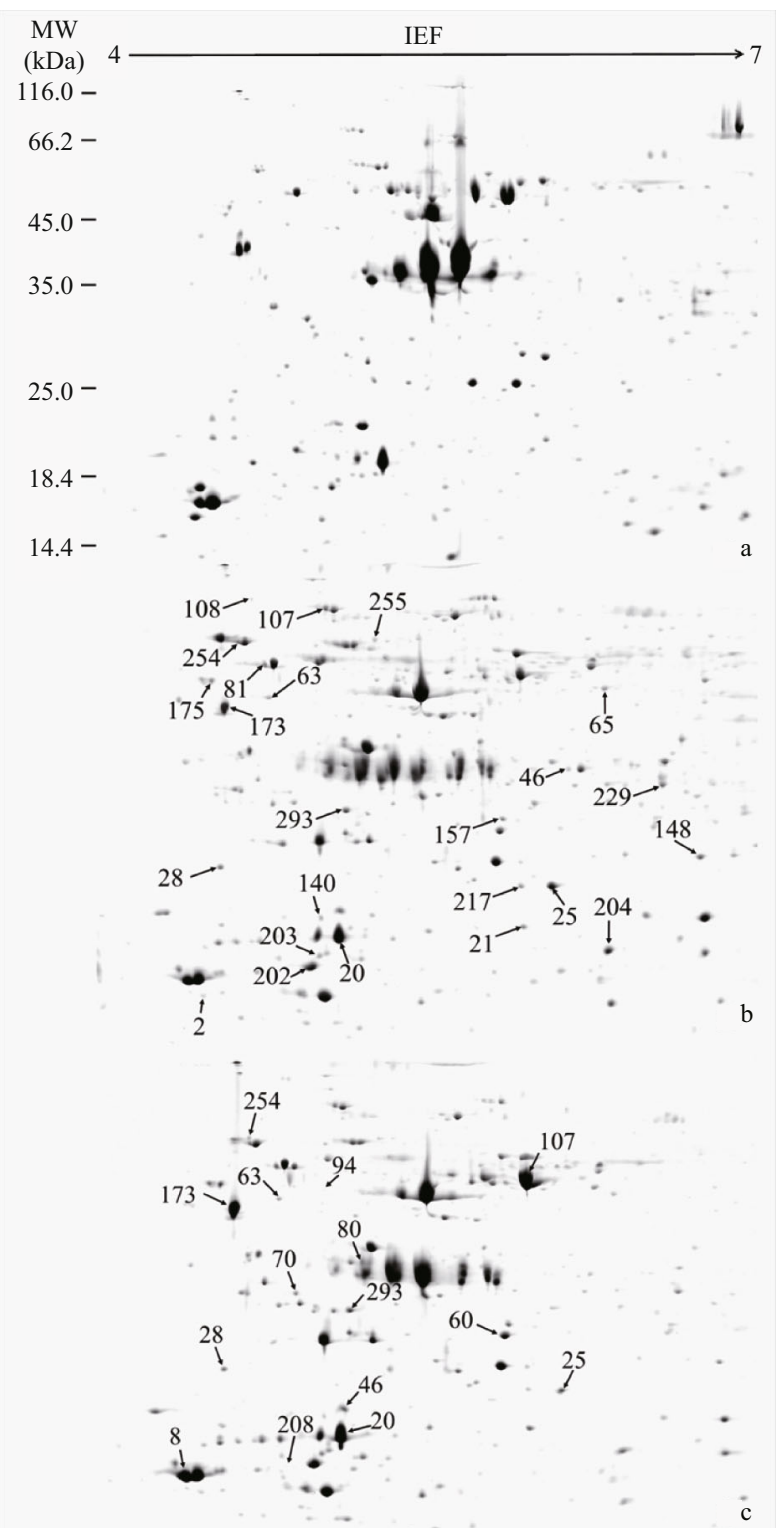

Fig.2 Representative 2-DE images from the tissues of oysters Crassostrea sikamea

Extracted proteins were submitted to isoelectric focusing on 4-7 IPG strips $(24 \mathrm{~cm})$ followed by electrophoresis on $12.5 \%$ SDSPAGE. Gels were stained by silver stain. Gels ( $a, b$ and $c$ ) of oyster samples are from (a) JZ, (b) JS and (c) BJ sites, respectively. The proteins spots observed in all three biological replicates were analyzed by MALDI-TOF/TOF mass spectrometry.

compared with those from the clean site (JZ). The detailed information of these differentially expressed proteins is summarized in Table 1.

In the oyster samples from JS site, 21 and 3 proteins were up-regulated and down-regulated, respectively. These proteins were primarily involved in metabolism, transcription and translation, cytoskeleton and movement, stress response, ion homeostasis, signal transduction and protein modification. Eight up- regulated and 7 down-regulated proteins with significances were found in the oyster samples from BJ site. Interestingly, there were 9 differentially expressed proteins (proteasome subunit beta type-3, phospholipase $\mathrm{D} 1,40 \mathrm{~S}$ ribosomal protein SA, F-actincapping protein subunit alpha, tropomyosin, heat shock protein beta-1, $78 \mathrm{kDa}$ glucose regulated protein, sarcoplasmic calcium-binding protein and protein disulfide isomerase) commonly found in the oyster samples from both JS and BJ sites.

Proteasomes were reported to be involved in multiple biological processes, including protein degradation, cell proliferation, apoptosis and stress responses (Zhang and Wei, 2011). The $78 \mathrm{kDa}$ glucose regulated protein belongs to the $70 \mathrm{kDa}$ heat shock protein family that is responsive to heavy metalinduced oxidative stress (Fontaine et al., 2003). Protein disulfide isomerase belongs to the superfamily of thioredoxin and functions as a catalyst of the formation and breakage of disulfide bonds in cysteine residues of folding proteins. This protein has been found in response to oxidative stress (Freedman et al., 1994). These three up-regulated proteins and heat shock protein beta-1 suggested that the metal pollutions in both JS and BJ sites induced oxidative stress in oysters. Interestingly, the $78 \mathrm{kDa}$ glucose regulated protein was also up-regulated in another species of oyster C. hongkongensis sampled in Baijiao and Fugong sites severely contaminated by $\mathrm{Cu}$ (Xu et al., 2016). Besides BJ site, JS site was also heavily polluted by $\mathrm{Cu}$, indicated by as high as $6746.7 \mu \mathrm{g} / \mathrm{g}$ $\mathrm{Cu}$ (dry weight) concentrated in oysters (Ji et al., 2016). Therefore, the $78 \mathrm{kDa}$ glucose regulated protein could be a protein biomarker of $\mathrm{Cu}$ pollution in oysters. Ribosomal proteins perform the crucial function of protein biosynthesis and have been also recognized as immunogenic proteins (Wang et al., 2013). The up-regulated $40 \mathrm{~S}$ ribosomal protein SA implied that the metal pollutions induced immune stress in oysters $C$. sikamea in JS and BJ sites. As an important $\mathrm{Ca}^{2+}$-binding system, sarcoplasmic calcium-binding proteins play key role in the maintenance of intracellular $\mathrm{Ca}^{2+}$ homeostasis (Gao et al., 2006). Therefore, the down-regulated sarcoplasmic calcium-binding protein meant the dysregulation of cellular $\mathrm{Ca}^{2+}$ homeostasis induced by metal pollutions in oysters $C$. sikamea. Phospholipase D is an enzyme that hydrolyses phosphatidylcholine to generate membrane-bound phosphatidic acid and soluble choline (Exton, 2002). It is involved in various cellular responses to growth factors (Exton, 2002). 
Table 1 List of protein spots that differentially expressed in oysters Crassostrea sikamea sampled from JS and BJ sites compared to $\mathrm{JZ}$ site

\begin{tabular}{|c|c|c|c|c|c|c|c|c|}
\hline Spot ID ${ }^{c}$ & Protein name & Accession number ${ }^{d}$ & MW (Da) & $\mathrm{p} I$ & Protein score ${ }^{e}$ & $\mathrm{SC}(\%)^{\mathrm{f}}$ & $\mathrm{PN}^{\mathrm{g}}$ & Fold changes $^{\mathrm{h}}$ \\
\hline \multicolumn{9}{|c|}{ Metabolism } \\
\hline 293 & Proteasome subunit beta type-3 & 405971643 & 18269 & 4.85 & 236 & 32 & 4 & $\begin{array}{l}1.63^{\mathrm{a}} \\
2.06^{\mathrm{b}}\end{array}$ \\
\hline 229 & Cathepsin B & 405971658 & 37664 & 6.31 & 618 & 32 & 7 & $1.92^{\mathrm{a}}$ \\
\hline 108 & Glucosidase 2 subunit beta & 405971250 & 58500 & 4.68 & 161 & 11 & 4 & $2.37^{\mathrm{a}}$ \\
\hline 28 & Phospholipase D1 & 405950944 & 184954 & 6.65 & 155 & 1 & 2 & $\begin{array}{l}1.71^{\mathrm{a}} \\
2.87^{\mathrm{b}}\end{array}$ \\
\hline 203 & Cytochrome b5 & 84619354 & 14589 & 5.03 & 475 & 48 & 4 & $2.04^{\mathrm{a}}$ \\
\hline 208 & Natterin-3 & 405971457 & 15510 & 6.50 & 75 & 11 & 1 & $-10.2^{\mathrm{b}}$ \\
\hline 2 & Cytochrome c oxidase subunit $5 \mathrm{~A}$, mitochondrial & 405959691 & 17970 & 4.89 & 104 & 13 & 2 & $3.45^{\mathrm{a}}$ \\
\hline \multicolumn{9}{|c|}{ Transcription and translation } \\
\hline 63 & 40S ribosomal protein SA & 405976088 & 33281 & 4.78 & 530 & 27 & 5 & $\begin{array}{l}1.84^{\mathrm{a}} \\
1.83^{\mathrm{b}}\end{array}$ \\
\hline 21 & Transcription factor BTF3-like protein 4 & 405970995 & 18383 & 6.17 & 554 & 61 & 5 & $22.6^{\mathrm{a}}$ \\
\hline \multicolumn{9}{|c|}{ Cytoskeleton and movement } \\
\hline 46 & F-actin-capping protein subunit alpha & 405951960 & 32291 & 5.77 & 667 & 42 & 8 & $\begin{array}{l}-5.69^{\mathrm{a}} \\
-1.79^{\mathrm{b}}\end{array}$ \\
\hline 65 & Actin & 2564711 & 41765 & 5.30 & 205 & 9 & 2 & $7.43^{\mathrm{a}}$ \\
\hline 81 & Severin & 405954824 & 37187 & 4.78 & 335 & 19 & 5 & $1.66^{\mathrm{a}}$ \\
\hline 173 & Tropomyosin & 219806594 & 33002 & 4.57 & 464 & 29 & 6 & $\begin{array}{l}-2.39^{\mathrm{a}} \\
-9.96^{\mathrm{b}}\end{array}$ \\
\hline 8 & Myosin essential light chain & 40642994 & 18217 & 4.53 & 495 & 42 & 6 & $1.88^{\mathrm{b}}$ \\
\hline 202 & Coactosin-like protein, partial & 405947827 & 12894 & 5.52 & 527 & 41 & 3 & $4.90^{\mathrm{a}}$ \\
\hline \multicolumn{9}{|c|}{ Stress response } \\
\hline 25 & Heat shock protein beta-1 & 405975485 & 19675 & 5.88 & 496 & 57 & 7 & $\begin{array}{c}3.37^{\mathrm{a}} \\
18.31^{\mathrm{b}}\end{array}$ \\
\hline 107 & $78 \mathrm{kDa}$ glucose regulated protein & 46359618 & 73030 & 5.02 & 571 & 12 & 6 & $\begin{array}{l}2.04^{\mathrm{a}} \\
1.91^{\mathrm{b}}\end{array}$ \\
\hline 148 & Protein lethal (2) essential for life & 405975484 & 20959 & 6.23 & 474 & 49 & 8 & $16.46^{\mathrm{a}}$ \\
\hline 204 & Superoxide dismutase $[\mathrm{Cu}-\mathrm{Zn}]$ & 405961012 & 15916 & 5.84 & 444 & 42 & 4 & $6.37^{\mathrm{a}}$ \\
\hline 80 & Extracellular superoxide dismutase $[\mathrm{Cu}-\mathrm{Zn}]$ & 405964323 & 21172 & 5.18 & 289 & 25 & 3 & $-3.14^{b}$ \\
\hline 255 & $60 \mathrm{kDa}$ heat shock protein, mitochondrial & 405966599 & 59671 & 5.51 & 604 & 19 & 6 & $11.57^{\mathrm{a}}$ \\
\hline 60 & Alpha-crystallin B chain & 405961891 & 23113 & 5.74 & 481 & 28 & 3 & $2.48^{\mathrm{b}}$ \\
\hline \multicolumn{9}{|c|}{ Ion homeostasis } \\
\hline 140 & Ferritin & 40643026 & 19958 & 5.05 & 195 & 27 & 3 & $1.86^{\mathrm{a}}$ \\
\hline 175 & Calumenin & 405957087 & 47629 & 4.46 & 459 & 25 & 6 & $6.47^{\mathrm{a}}$ \\
\hline 20 & Sarcoplasmic calcium-binding protein & 405963559 & 21124 & 4.96 & 588 & 49 & 7 & $\begin{array}{l}-6.90^{\mathrm{a}} \\
-2.57^{\mathrm{b}}\end{array}$ \\
\hline \multicolumn{9}{|c|}{ Signal transduction } \\
\hline 70 & 14-3-3 protein zeta & 405950098 & 35128 & 4.78 & 491 & 27 & 5 & $-1.64^{\mathrm{b}}$ \\
\hline 157 & Growth factor receptor-bound protein 2 & 405970772 & 22617 & 5.62 & 524 & 42 & 5 & $6.43^{\mathrm{a}}$ \\
\hline \multicolumn{9}{|c|}{ Protein modification } \\
\hline 254 & Protein disulfide isomerase & 405964146 & 55465 & 4.62 & 510 & 19 & 7 & $\begin{array}{l}2.08^{\mathrm{a}} \\
2.52^{\mathrm{b}}\end{array}$ \\
\hline 94 & Protein phosphatase 1B & 405972778 & 90964 & 5.17 & 474 & 7 & 4 & $-7.01^{b}$ \\
\hline 217 & Peptidyl-prolyl cis-trans isomerase $\mathrm{C}$ & 405972618 & 15855 & 9.47 & 370 & 32 & 3 & $1.90^{\mathrm{a}}$ \\
\hline
\end{tabular}

a, b: identification of differentially expressed proteins in tissues of oysters Crassostrea sikamea from JS and BJ, compared to the oyster samples from JZ;

c: assigned spot ID as indicated in Figure 2; d: GI numbers in NCBInr database; ${ }^{\mathrm{e}}$ : mascot score reported. $\mathrm{f}:$ sequence coverage; g: number of peptide sequences;

h: fold changes with significant changes $(>1.5$ folds and $P<0.05)$ were calculated using ImageMaster 2D Platinum 7.0. 
The up-regulated phospholipase D1 might suggest that metal pollutions affected the growth of oysters in JS and BJ sites. F-actin-capping protein is an actinbinding protein involved in the regulation of actin dynamics (Hartmann et al., 1989). Tropomyosin is a regulator of muscle contraction existing in muscle and non-muscle cells (Fujinoki et al., 2006). These two cytoskeleton related proteins demonstrated the cellular injury caused by metal pollutions in oysters.

In invertebrate, cathepsin B contributes to the digestion of blood protein and plays a role in innate immunity (Dorts et al., 2011). Growth factor receptor bound protein 2 is involved in immune signaling pathways (Saito and Yamasaki, 2003). The upregulated cathepsin B and growth factor receptor bound protein indicated the immune stress induced by metal pollution in oysters from JS site. Both actin and coactosin-like protein are cytoskeletal proteins (Puerto et al., 2011). Severin is a protein that severs actin filaments in a $\mathrm{Ca}^{2+}$-dependent manner and remains bound to the filament fragments (Giffard et al., 1984). Glucosidase 2 is a glycoprotein-processing enzyme and its absence may trigger the unfolded protein response which may help cells to avoid cellular injury through the aggregation of mal-folded proteins (Taylor et al., 2000). As glucosidase 2 is related to the quality control of glycoproteins, it might be up-regulated under the conditions of unfolded protein response (Geysens et al., 2005). Therefore, these four up-regulated proteins clearly revealed the cellular injury caused by metal pollution in the oysters from JS site, together with down-regulated F-actincapping protein and tropomysion. As ubiquitous electron transport hemoproteins, cytochrome b5s were reported to be induced by xenobiotics, such as heavy metals (Zhang et al., 2012b). Cytochrome c oxidase is an important cellular enzyme with a central role in oxidative metabolism (Stiburek et al., 2006) and the activity of cytochrome c oxidase can be used as an indicator of mitochondrial quantity and quality (Čapková et al., 2002). Cu is the main metal pollutant in the JS site ( $\mathrm{Ji}$ et al., 2016). As reported, $\mathrm{Cu}$ can influence mitochondrial function by inducing oxidative stress and reducing the amount of energy from oxidative phosphorylation (Krumschnabel et al., 2005). Therefore, the elevated cytochrome b5 and cytochrome c oxidase suggested the oxidative stress induced by metal pollution, especially $\mathrm{Cu}$, in the oysters from JS site. Protein lethal (2) essential for life belongs to the family of small heat shock family which was responsive to heavy metal-induced oxidative stress (Kurzik-Dumke and Lohmann, 1995; Fontaine et al., 2003). Peptidyl-prolyl cis-trans isomerase is involved in post-transcriptional modification processes such as protein folding and plays a role against oxidative stress (Esperanza et al., 2015). In addition, other proteomic responses related to oxidative stress, including superoxide dismutase $[\mathrm{Cu}-\mathrm{Zn}]$ and $60 \mathrm{kDa}$ heat shock protein, were also significantly elevated. These elevated proteins confirmed the oxidative stress induced by metal pollution in oysters, as mentioned above. Ferritin is a universal intracellular protein that has two functions, iron detoxification and iron storage, playing a vital role in the cellular homeostasis of iron for the cell by storing excess iron (Durand et al., 2004). This protein was up-regulated in the oysters from JS site, in which the average concentration of Fe was over 7 folds higher than those from JZ site (Data not published). Interestingly, one significantly up-regulated ferritin had been also observed in oysters $C$. hongkongensis from Fe-polluted site (Xu et al., 2016). Therefore, ferritin could be used as the protein biomarker of Fe contamination in oysters. Calumenin has been identified as an important sarcoplasmic reticulum luminal protein that regulates $\mathrm{Ca}^{2+}$ homeostasis in muscle cells (Sahoo et al., 2009). The up-regulated calumenin meant the dysregulation of $\mathrm{Ca}^{2+}$ homeostasis induced by metal pollution in oysters C. sikamea from JS site, together with the downregulated sarcoplasmic calcium-binding protein. Transcription factor BTF3 protein forms a stable complex with RNA polymerase II B and is required for transcriptional initiation (Jiang et al., 2014). The elevated transcription factor BTF3-like protein 4 implied the enhanced transcriptional initiation induced by metal pollution in oysters from JS site.

Alpha-crystallin B chain belongs to a small stress protein related to small heat shock protein family (Fontaine et al., 2003). The altered alpha-crystallin B chain and extracellular superoxide dismutase $[\mathrm{Cu}-\mathrm{Zn}]$ meant the oxidative stress in oysters from BJ site. The myosin essential light chain plays roles in building the actomyosin cross-bridge which is related to cell structure (Tian et al., 2011). The down-regulated myosin essential light chain combined with F-actincapping protein subunit alpha and tropomyosin implied cellular injury induced by metal pollution in oysters from BJ site. The 14-3-3 proteins was reported to be capable of preventing apoptosis by binding diverse signaling proteins, such as transmembrane receptors kinases and phosphatases (Muslin et al., 
1996). As reported previously, low salinity stress could down-regulate 14-3-3 protein in clam Ruditapes philippinarum (Wu et al., 2013b). Interestingly, one 14-3-3 protein and one protein phosphatase were simultaneously down-regulated, which suggested that metal pollution induced apoptosis in oysters from BJ site. Natterins are identified as a novel family of proteins from the venom of Thalassophyrne nattereri (Magalhães et al., 2005). They have kininogenase activity and can cause nociception and edema, confirming their role as stone fish toxins (Magalhães et al., 2005). In addition, natterin may also exert a direct cytotoxicity. Natterin has also been found in Pacific oyster $C$. giggas by Zhang et al. (2012a). In this work, one natterin was significantly downregulated in metal pollution-exposed oyster C. sikamea from BJ site. The down-regulated natterin likely implied that the oysters tried to down-regulate natterin to reduce the cytotoxicity (cellular injury) induced by metal pollution.

\section{CONCLUSION}

Due to the industrial development, the Jiulongjiang estuary in South China has been polluted by metals, including $\mathrm{Cu}, \mathrm{Zn}, \mathrm{Cd}, \mathrm{Fe}$ and so on. In this study, twodimensional electrophoresis (2-DE)-based proteomics was used to investigate the biological effects of metal pollutions in the oysters C. sikamea from metal pollution sites, Jinshan and Baijiao, along the Jiulongjiang estuary. Results indicated that metal pollutions mainly induced cellular injuries, oxidative and immune stresses, and disturbed ion homeostasis in oysters C. sikamea from both JS and BJ sites via differential pathways. Furthermore, metal pollution enhanced transcriptional initiation in oysters from JS site. In addition, $78 \mathrm{kDa}$ glucose regulated protein and ferritin GF1 might be used as the biomarkers of $\mathrm{Cu}$ and $\mathrm{Fe}$ in oyster C. sikamea, respectively.

\section{DATA AVAILABILITY STATEMENT}

The NCBInr Metazoa (Animals) (2 861494 sequences) database used for protein identification during the current study were available in the NCBI database (2013) (https://www.ncbi.nlm.nih.gov/protein), where the accession numbers and the protein names of the differentially expressed proteins generated in the study were provided.

\section{References}

Bertin G, Averbeck D. 2006. Cadmium: cellular effects, modifications of biomolecules, modulation of DNA repair and genotoxic consequences (a review). Biochimie, 88(11): 1 549-1 559.

Campos A, Tedesco S, Vasconcelos V, Cristobal S. 2012. Proteomic research in bivalves: towards the identification of molecular markers of aquatic pollution. J. Proteomics, 75(14): 4 346-4 359.

Čapková M, Houštěk J, Hansíková H, Hainer V, Kunešová M, Zeman J. 2002. Activities of cytochrome c oxidase and citrate synthase in lymphocytes of obese and normalweight subjects. Int. J. Obes., 26(8): 1 110-1 117.

Cappello T, Mauceri A, Corsaro C, Maisano M, Parrino V, Lo Paro G, Messina G, Fasulo S. 2013. Impact of environmental pollution on caged mussels Mytilus galloprovincialis using NMR-based metabolomics. Mar. Pollut. Bullet., 77(1-2): 132-139.

Cecconi I, Scaloni A, Rastelli G, Moroni M, Vilardo P G, Costantino L, Cappiello M, Garland D, Carper D, Petrash J M, Del Corso A, Mura U. 2002. Oxidative modification of aldose reductase induced by copper ion. Definition of the metal-protein interaction mechanism. J. Biol. Chem., 277(44): 42 017-42 027.

Dorts J, Kestemont P, Dieu M, Raes M, Silvestre F. 2011. Proteomic response to sublethal cadmium exposure in a sentinel fish species, Cottus gobio. J. Proteome Res., 10(2): 470-478.

Durand J P, Goudard F, Pieri J, Escoubas J M, Schreiber N, Cadoret J P. 2004. Crassostrea gigas ferritin: cDNA sequence analysis for two heavy chain type subunits and protein purification. Gene, 338(2): 187-195.

Esperanza M, Seoane M, Rioboo C, Herrero C, Cid Á. 2015. Chlamydomonas reinhardtii cells adjust the metabolism to maintain viability in response to atrazine stress. Aquat. Toxicol., 165: 64-72.

Exton J H. 2002. Regulation of phospholipase D. FEBS Lett., 531(1): 58-61.

Fontaine J M, Rest J S, Welsh M J, Benndorf R. 2003. The sperm outer dense fiber protein is the 10th member of the superfamily of mammalian small stress proteins. Cell Stress Chaperon., 8(1): 62-69.

Freedman R B, Hirst T R, Tuite M F. 1994. Protein disulphide isomerase: building bridges in protein folding. Trends Biochem. Sci., 19(8): 331-336.

Fujinoki M, Ueda M, Inoue T, Yasukawa N, Inoue R, IshimodaTakagi T. 2006. Heterogeneity and tissue specificity of tropomyosin isoforms from four species of bivalves. Comp. Biochem. Physiol. B Biochem. Mol. Biol., 143(4): 500-506.

Gao Y P, Gillen C M, Wheatly M G. 2006. Molecular characterization of the sarcoplasmic calcium-binding protein (SCP) from crayfish Procambarus clarkii. Comp. Biochem. Physiol. B Biochem. Mol. Biol., 144(4): 478487.

Geysens S, Pakula T, Uusitalo J, Dewerte I, Penttilä M, Contreras R. 2005. Cloning and characterization of the glucosidase II alpha subunit gene of Trichoderma reesei: a frameshift mutation results in the aberrant glycosylation 
profile of the hypercellulolytic strain Rut-C30. Appl. Environ. Microbiol., 71(6): 2 910-2 924.

Giffard R G, Weeds A G, Spudich J A. 1984. $\mathrm{Ca}^{2+}$-dependent binding of severin to actin: a one-to-one complex is formed. J. Cell Biol., 98(5): 1 796-1 803.

Goldberg E D, Koide M, Hodge V, Flegal A R, Martin J. 1983. U. S. mussel watch: 1977-1978 results on trace metals and radionuclides. Est. Coast. Shelf Sci., 16(1): 69-93.

Hartmann H, Noegel A A, Eckerskorn C, Rapp S, Schleicher M. 1989. $\mathrm{Ca}^{2+}$-independent $\mathrm{F}$-actin capping proteins. Cap 32/34, a capping protein from Dictyostelium discoideum, does not share sequence homologies with known actinbinding proteins. J. Biol. Chem., 264(21): 12 639-12 647.

Hines A, Oladiran G S, Bignell J P, Stentiford G D, Viant M R. 2007. Direct sampling of organisms from the field and knowledge of their phenotype: key recommendations for environmental metabolomics. Environ. Sci. Technol., 41(9): 3 375-3 381.

Ji C L, Wang Q, Wu H F, Tan Q G, Wang W X. 2016. A metabolomic study on the biological effects of metal pollutions in oysters Crassostrea sikamea. Mar. Pollut. Bullet., 102(1): 216-222.

Jiang W D, Liu Y, Hu K, Jiang J, Li S H, Feng L, Zhou X Q. 2014. Copper exposure induces oxidative injury, disturbs the antioxidant system and changes the Nrf2/ARE (CuZnSOD) signaling in the fish brain: protective effects of myo-inositol. Aquat. Toxicol., 155: 301-333.

Katayama H, Nagasu T, Oda Y. 2001. Improvement of in-gel digestion protocol for peptide mass fingerprinting by matrix-assisted laser desorption/ionization time-of-flight mass spectrometry. Rapid Commun. Mass Spectrom., 15(16): 1 416-1 421.

Kim S H, Jung M Y, Lee Y M. 2011. Effect of heavy metals on the antioxidant enzymes in the marine ciliate Euplotes crassus. Toxicol. Environ. Health Sci., 3(4): 213-219.

Knigge T, Monsinjon T. Andersen O K. 2004. Surfaceenhanced laser desorption/ionization-time of flight-mass spectrometry approach to biomarker discovery in blue mussels (Mytilus edulis) exposed to polyaromatic hydrocarbons and heavy metals under field conditions. Proteomics, 4(9): 2 722-2 727.

Krumschnabel G, Manzl C, Berger C, Hofer B. 2005. Oxidative stress, mitochondrial permeability transition, and cell death in Cu-exposed trout hepatocytes. Toxicol. Appl. Pharmacol., 209(1): 62-73.

Kurzik-Dumke U, Lohmann E. 1995. Sequence of the new Drosophila melanogaster small heat-shock-related gene, lethal(2) essential for life [l(2)efl], at locus 59F4,5. Gene, 154(2): 171-175.

Lin C Q, Yu R L, Hu G R, Yang Q L, Wang X M. 2016. Contamination and isotopic composition of $\mathrm{Pb}$ and $\mathrm{Sr}$ in offshore surface sediments from Jiulong River, Southeast China. Environ. Pollut., 218: 644-650.

Liu F J, Wang W-X. 2012. Proteome pattern in oysters as a diagnostic tool for metal pollution. J. Hazard. Mater., 239-240: 241-248.

Luo L Z, Ke C H, Guo X Y, Shi B, Huang M Q. 2014. Metal accumulation and differentially expressed proteins in gill of oyster (Crassostrea hongkongensis) exposed to longterm heavy metal-contaminated estuary. Fish Shellfish Immunol., 38(2): 318-329.

Magalhães G S, Lopes-Ferreira M, Junqueira-de-Azevedo I L M, Spencer P J, Araújo M S, Portaro F C V, Ma L, Valente R H, Juliano L, Fox J W, Ho P L, Moura-da-Silva A M. 2005. Natterins, a new class of proteins with kininogenase activity characterized from Thalassophryne nattereri fish venom. Biochimie, 87(8): 687-699.

Monsinjon T, Knigge T. 2007. Proteomic applications in ecotoxicology. Proteomics, 7(16): 2 997-3 009.

Muslin A J, Tanner J W, Allen P M, Shaw A S. 1996. Interaction of 14-3-3 with signaling proteins is mediated by the recognition of phosphoserine. Cell, 84(6): 889-897.

Puerto M, Campos A, Prieto A, Cameán A, de Almeida A M, Coelho A V, Vasconcelos V. 2011. Differential protein expression in two bivalve species; Mytilus galloprovincialis and Corbicula fluminea; exposed to Cylindrospermopsis raciborskii cells. Aquat. Toxicol., 101(1): 109-116.

Rank J, Lehtonen K K, Strand J, Laursen M. 2007. DNA damage, acetylcholinesterase activity and lysosomal stability in native and transplanted mussels (Mytilus edulis) in areas close to coastal chemical dumping sites in Denmark. Aquat. Toxicol., 84(1): 50-61.

Sahoo S K, Kim T, Kang G B, Lee J G, Eom S H, Kim DH. 2009. Characterization of calumenin-SERCA2 interaction in mouse cardiac sarcoplasmic reticulum. J. Biol. Chem., 284(45): 31 109-31 121.

Saito T, Yamasaki S. 2003. Negative feedback of T cell activation through inhibitory adapters and costimulatory receptors. Immunol. Rev., 192(1): 143-160.

Shevchenko A, Wilm M, Vorm O, Mann M. 1996. Mass spectrometric sequencing of proteins from silver-stained polyacrylamide gels. Anal. Chem., 68(5): 850-858.

Stiburek L, Hansikova H, Tesarova M, Cerna L, Zeman J. 2006. Biogenesis of eukaryotic cytochrome c oxidase. Physiol. Res., 55(S2): S27-S41.

Tan Q G, Wang Y, Wang W X. 2015. Speciation of Cu and Zn in two colored oyster species determined by X-ray absorption spectroscopy. Environ. Sci. Technol., 49(11): 6919-6925.

Taylor M A, Ross H A, McRae D, Stewart D, Roberts I, Duncan G, Wright F, Millam S, Davies H V. 2000. A potato $\alpha$-glucosidase gene encodes a glycoproteinprocessing $\alpha$-glucosidase II-like activity. Demonstration of enzyme activity and effects of down-regulation in transgenic plants. Plant J., 24(3): 305-316.

Tian L, Wang M H, Li X M, Lam P K S, Wang M F, Wang D Z, Chou H N, Li Y, Chan LL. 2011. Proteomic modification in gills and brains of medaka fish (Oryzias melastigma) after exposure to a sodium channel activator neurotoxin. brevetoxin-1. Aquat. Toxicol., 104(3-4): 211-217.

Tomanek L. 2014. Proteomics to study adaptations in marine organisms to environmental stress. J. Proteomics, 105: 92-106. 
Vidal-Liñán L, Bellas J. 2013. Practical procedures for selected biomarkers in mussels, Mytilus galloprovincialisimplications for marine pollution monitoring. Sci. Total Environ., 461-462: 56-64.

Wang J Y, Lan P, Gao H M, Zheng L, Li W F, Schmidt W. 2013. Expression changes of ribosomal proteins in phosphate- and iron-deficient Arabidopsis roots predict stress-specific alterations in ribosome composition. $B M C$ Genomics, 14: 783 .

Weng N, Wang W X. 2014. Variations of trace metals in two estuarine environments with contrasting pollution histories. Sci. Total Environ., 485-486: 604-614.

Wu H F, Ji C L, Wei L, Zhao J M. 2013a. Evaluation of protein extraction protocols for 2DE in marine ecotoxicoproteomics. Proteomics, 13(21): 3 205-3 210.

Wu H F, Liu X L, Zhang X Y, Ji C L, Zhao J M, Yu J B. 2013 b. Proteomic and metabolomic responses of clam Ruditapes philippinarum to arsenic exposure under different salinities. Aquat. Toxicol., 136-137: 91-100.

Xu L L, Ji C L, Wu H F, Tan Q G, Wang W-X. 2016. A comparative proteomic study on the effects of metal pollution in oysters Crassostrea hongkongensis. Mar. Pollut. Bullet., 112(1-2): 436-442.

Zhang G F, Fang X D, Guo X M, Li L, Luo R B, Xu F, Yang P C, Zhang L L, Wang X T, Qi H G, Xiong Z Q, Que H Y,
Xie Y L, Holland P W H, Paps J, Zhu Y B, Wu F C, Chen Y X, Wang J F, Peng C F, Meng J, Yang L, Liu J, Wen B, Zhang N, Huang Z Y, Zhu Q H, Feng Y, Mount A, Hedgecock D, Xu Z, Liu Y J, Domazet-Lošo T, Du Y S, Sun X Q, Zhang S D, Liu B H, Cheng P Z, Jiang X T, Li J, Fan D D, Wang W, Fu W J, Wang T, Wang B, Zhang J B, Peng Z Y, Li Y X, Li N, Wang J P, Chen M S, He Y, Tan F J, Song X R, Zheng Q M, Huang R L, Yang H L, Du X D, Chen L, Yang M, Gaffney P M, Wang S, Luo L H, She Z C, Ming Y, Huang W, Zhang S, Huang B Y, Zhang Y, Qu T, Ni P X, Miao G Y, Wang J Y, Wang Q, Steinberg C E, Wang H Y, Li N, Qian L M, Zhang G J, Li Y R, Yang H M, Liu X, Wang J, Yin Y, Wang J. 2012a. The oyster genome reveals stress adaptation and complexity of shell formation. Nature, 490(7418): 49-54.

Zhang L B, Gan J L, Ke C L, Liu X L, Zhao J M, You L P, Yu J B, Wu H F. 2012b. Identification and expression profile of a new cytochrome P450 isoform (CYP414A1) in the hepatopancreas of Venerupis (Ruditapes) philippinarum exposed to benzo[a]pyrene, cadmium and copper. Environ. Toxicol. Pharmacol., 33(1): 85-91.

Zhang W, Wei Q. 2011. Calcineurin stimulates the expression of inflammatory factors in RAW 264.7 cells by interacting with proteasome subunit alpha type 6. Biochem. Biophys. Res. Commun., 407(4): 668-673. 